\title{
Taking an Expended View of Customer to Construct Hotel Rating System
}

\author{
Jui-Ying Hung \\ Department of Senior Citizen Service Management, Chaoyang University of Technology, Taichung, Taiwan \\ Tel: 886-423-323-000-7641Ｅ-mail: jybong@cyut.edu.tw \\ Feng-Li Lin (Corresponding author) \\ Department of Accounting, Chaoyang University of Technology, Taichung, Taiwan \\ Tel: 886-423-323-000-7421Ｅ-mail: fengli168@gmail.com
}

\author{
Received: January 29, $2012 \quad$ Accepted: February 8, $2012 \quad$ Published: April 1, 2012 \\ doi:10.5539/ibr.v5n4p12 \\ URL: http://dx.doi.org/10.5539/ibr.v5n4p12
}

\begin{abstract}
An attention on leisure consciousness and related activities by Taiwan people also signifies an enhanced standard on service quality and demand satisfaction of tourism and leisure industry, in which a perception of customer satisfaction perceived by consumers in terms of appraisal dimension and measurement was gradually replaced by intangible accommodation experience or personalized service by service personnel from tangible hardware facilities and equipments in the past. Tourism Bureau of Republic of China has recently announced the execution of "hotel rating system" which suspended for nearly twenty, an announcement of this policy has caused considerable echoes and support to scholars from the academy and the industry and consumers with regard to hotel business, the hotel industry in Taiwan will only be able to get connected with international tourism market so as to inspire the global awareness of tourism market in Taiwan through the implementation of "hotel rating system". The study follows the assessment standards of "star hotel rating system" promoted and implemented by Tourism Bureau, Ministry of Transportation and Communications (MOTC) in 2010, to conduct analysis in terms of SERVQUAL's five dimensions proposed by Parasuraman, Zeithamel and Berry (1985). According to the research results, the hotel rating system in Taiwan is badly in need of an attention to the establishment and assessment of indicators in terms of "service assurance" and "service empathy" dimensions, the results also indicated that tourists make judgment based on "tangible hardware" along with "intangible service" provided by the hotels, are important determinants to enable a differentiation.
\end{abstract}

Keywords: Hotel management, Hotel rating system, Fuzzy delphi method, Fuzzy, Analytic hierarchy process

\section{Research Background}

The World Tourism Organization (WTO) has proposed the "Tourism 2020 Vision" since 1995; forecasting an up to $\$ 1.6 \mathrm{~T}$ revenues achieved by "tourism" in 2020, where the number of visitors will be increased up to $1.62 \mathrm{~B}$ visits worldwide, Europe (717m visits) is the primary region which attracts more number of visitors to come in 2020 , followed by East Asia \& Pacific regions (397m visits) and USA (282m visits), in which the tourism markets in East Asia \& Pacific regions expect a $5 \%$ annual growth, which is slightly higher than a $4.1 \%$ annual growth of global tourist population, showing that East Asia \& Pacific regions are the most potential and expandable areas of global tourism market in the future.

According to related statistics and forecast on the tourism industry's contribution to the global economy conducted by World Travel \& Tourism Committee (WTTC), the global tourism industry in 2009 (including tourism related industries, investment and tax income) comprised a $10.3 \%$ of world GDP, which is equivalent to \$4.964T. And as 2016, the global tourism industry will expect to attain a $10.9 \%$ of world GDP, which equivalent to $\$ 8 \mathrm{~T}$ and $\$ 971.6 \mathrm{~B}$, in which WTTC said that the tourism industry in Taiwan reported a decline in terms of ranking on 3 key indicators absolute economic output, relative contribution to national economy, and forecast on economic growth though it reported a trend of continuous growth in 2007.

Based on the optimistic forecast and analysis of global tourism industry by primary tourism research institutes in the world, how does Taiwan break through the current tourism market, think and propose tourism policies that report 
sustainable development and remarkable effects, and the middle-/long-term tourism development plan to react to an era of diverse tourism marketing tactics that emerge in an endless stream? In fact, Taiwan has opened up to residents in Mainland China for tourism activities in Taiwan through off-shore islands (Kinmen county and Matse county) on July $15^{\text {th }} 2008$; expecting to get rid of a closed and passive tourism marketing manner through government's policy deregulation formerly to further get into other countries through a manner of enthusiasm, diverse creativity and spokesperson, to develop the awareness of Taiwan in the world and to attract more potential visitors to come visit Taiwan. However, many tourism activities mentioned above are all countermeasures of Taiwan while facing global tourism market, whether the tourism and travel industry inside Taiwan has to simultaneously enhance its global competitiveness and jointly create a Taiwan tourism market with charisma and distinguishing feature.

The Tourism Bureau of MOTC has recently announced that the "hotel rating system" which implemented in 1983 and suspended for nearly 20 years since 1989, this news has caused considerable echoes and support from scholars from the academy and the industry and consumers with regard to hotel business, the hotel industry in Taiwan will only be able to get connected with international tourism market through the implementation of "hotel rating system", so as to inspire the global awareness of tourism market in Taiwan, to stimulate the tourism image of tourists coming to Taiwan and to inspire the economic output of tourism market in Taiwan and the global competitiveness.

The purpose of re-promotion and implementation of hotel rating system is nothing but mainly about enhancement of global competitiveness of Taiwan tourism market, to improve the uneven quality of Taiwan hotels, insufficiency of fair pricing mechanism, integrated information for room booking and practice guidelines, which result in many negative image issues such as consumption disputes and arguments etc., to further attract more overseas visitors to visit and spend money in Taiwan, to increase foreign exchange earnings and to inspire an awkward situation of economic recession which lacks consumer confidence in Taiwan for the time being.

Hotel business has to be an industry which combines both tangible hardware (architecture, facility and equipment) and intangible software (service, atmosphere). According to Lewis (1989), intangible product is the most important part among hotel products, in which a process of excellent service delivery by service personnel will enable a concrete and effective marketing strategy and industry feature to the intangible service of the hotel. In which, the definition and measurement criteria of tangible hardware can be judged upon objective, fair and square indicators, while intangible software is inseparable to tangible hardware/facility and equipment, intangible software have to provide customized and differentiated service upon actual condition, which cannot be provided with a manner of output stored or simulated in advance. Lastly, whether the heterogeneity characteristics of intangible service (a difference existed in interactive outcome generated from a variance of who, what, when, where, why and how) is the most difficult part for hotel business to conquer, or the hardest part to exactly measure whether the given effect is achieved? Will tourists feel the effort of hotel or service personnel? These many tangible interactions at a key moment are key factor that affects tourists' judgment on hotel perception.

According to the viewpoints of characteristics of hotel industry, if the current hotel rating system design and implementation of hotel rating system executed by Tourism Bureau, MOTC fail to follow the overall system concept through SERVQUAL's dimensions proposed by Parasuraman et al. (1985) which classify the existing hotel assessment items, and conduct hierarchy analysis of research result upon a manner of hierarchy architecture and provided as a reference for the use of practice and theory verification among the academy/government/industry fields, will be primary research questions of the study.

The study aims to achieve below research purposes upon the contents and directions of above research questions:

- The SERVQUAL dimension upon PZB covers hierarchical hotel rating system of software/hardware concepts, to differentiate hotel business by nature of activity through hotel's organization structure and job responsibility, this will refer to SERVQUAL's dimension by Parasuraman et al. (1985) to divide tier-1 primary dimensions of hotel rating system into service assurance, service responsiveness, service tangibility dimension and service empathy, and to develop a "hierarchical hotel rating system" upon the "hotel rating system" covering architecture equipment and service quality assessment standards etc. implemented by Tourism Bureau, MOTC in terms of these two major dimensions afterwards.

- Key success factors to the development of hotel industry operation in Taiwan.

Develop overall hotel rating system of hierarchy importance, weight ratio and related judgment guidelines after deleting the assessment items without expert consensus upon Fuzzy Delphi Method and Fuzzy Analytic Hierarchy Process (FAHP).

\section{Literature Review}

This is mainly about discussion and analysis of various hotel rating systems and literature review with regard to 
hotel rating system and lastly, to combine with the organization structure and job descriptions of hotel business through the primary concepts of SERVQUAL dimension by Parasuraman et al. (1985) to develop the prototype of hotel rating system established by the research plan upon discussion and analysis of various hotel rating system.

\subsection{Discussion and Analysis of Hotel Rating Systems of the World}

The hotel rating system of the world all pay attention to tourism \& travel industry development which is regarded as potential star industry in the $21^{\text {st }}$ century along with IT technology. Furthermore, the scope of human activity and leisure life gradually extends to spatial category with the development of vehicles and rapid growth of a booming economy, which breaks through the barrier caused by time and gap caused by culture and unveils the beginning of a new era. In the meantime, The "hotel" industry plays a decisive role in an era of rising tourism concept, of course the hotel related study organizations in the world all emphasize on establishing ratings system of hotel industry; expecting to provide a fair and objective reference of overall hotel image to consumers, however, being limited by different industry environment, business culture background and operation type of various countries, there has no one standard which generally acknowledged by ratings organization or systems as of now.

The most noted hotel rating system for the time being is the rating system used by American Automobile Association (AAA), in which the AAA began to design the standards for hotel rating system since 1977, with scope of assessment subject to USA, Canada, Mexico and Caribbean based hotels, the hotel accommodation rating by AAA is conducted once a year with contents to cover hotel appearance, room facility and equipment, public areas, clearance, management and service quality. Acceptance of evaluation is free of payment simply becoming a member by registration, those who expect to hang a diamond mark will need to pay after the evaluation; in which the anonymous who report professional insight will be assigned by AAA to conduct hotel evaluation process without precaution during the evaluation process, and lastly, to award a certificate of 1-5 star diamond for hotel suppliers to post and announce. The contents of segmentation standards for hotel rating by WTO include number of guest rooms, facility and equipment, service items, service quality and employee quality. While the evaluation at UK, Italy, Greece and Switzerland in Europe region will roughly subject to service items, equipment \& facility, geography and appearance. The Institutional Investors PLC will select 100 noted bankers in the world as evaluation commissioners annually to conduct ranking of world hotels, in which the geography, architecture style, equipment $\&$ facility and service quality over the years are what highly emphasized by the tourists.

Mobil Oil Corporation will take the opinions of experts from domestic/overseas travel and food \& beverage business into account to enable an objective evaluation process without losing the feature of various hotels. The primary scope of evaluation in this system is quality, decoration, repair \& maintenance, room affairs, general service and $\mathrm{F}$ \& B service of hardware facility, while the distinctive features of climatic, historical, cultural and artistic value of various evaluation hotels regionally are also the key assessment factors, in which a rating from 1-5 star after evaluation will be rendered, this ratings system requires attainment of every item on the checklist is also one of features for this rating system.

The hotel rating system of Canada is managed by an integrated organization established by the government. In order to save the budget expenditure, the evaluation is conducted biennially, the recruitment of member is by volunteer application while the evaluation is conducted upon irregular manner without warning, and related evaluators will directly execute the evaluation matter through intensive training. The crown rating system promoted by the English Tourist Boards (ETBs) is conducted once a year, the implementation of evaluation is divided into two parts - quality assessment and ratings assessment, the suppliers will be able to freely choose either one to conduct assessment, and suppliers have to pass "rating assessment" first if suppliers wish to participate in "quality assessment". "Quality assessment" is to categorize the quality of all facilities and services of hotels, to give a comprehensive appraisal of facts that are strong enough to affect visitor impression such as room décor, well crisis management capability, the rating evaluated can be divided into "approved", "commended", "highly commended" and "deluxe"; while the "rating assessment" will be evaluated in terms of hotel facility and service with scale ranged from crown 1-5 as its mark.

The hotel rating system of Mainland China is currently unified and established by the National Tourism Administration of the People's Republic of China, called "People's Republic of China tourism (foreign) Hotel Stars standard" with hotel rating segmented by 1 to 5 star. The evaluation organization of hotel star rating under the National Tourism Administration is responsible for conducting evaluation of 3-5 star hotels. This evaluation items cover architecture, equipment, décor, facility requirement and repair \& maintenance, management standard and level of service quality, number of service items.

In order to actively maintain the basic rights of hotels under the governance of choosing period of local/overseas visitor, the Taipei City Government has established the brand image of hotel itself to achieve the ultimate goal of 
effective hotel and city marketing by awarding the mark for identification. Therefore, China Credit Information Service Ltd. executes the hotel assessment system on the general hotels in Taipei under the commission of the Department of Transportation, Taipei City Government. The execution process of hotel rating system by Taipei City Government is divided into two stages - stage 1: self-assessment of suppliers, i.e. the suppliers have to subject to the written information of self-assessment to the organizer - Taipei City Department of Transportation, with the $2^{\text {nd }}$ stage evaluation conducted after filing and a review; while the $2^{\text {nd }}$ stage is to conduct field assessment by evaluation team, in which the members of evaluation team are composed of building administration, fire prevention, hygiene, environment protection and consumer protection areas of expertise, while the hotel rating system is mainly divided into overall environment, maintenance of room facility, business management and service management of hotels, with 20 sub-evaluation items formed to conduct assessment. The hotel rating system is designed upon a hierarchical concept with the indicators covered by various sub-evaluation items total up 100 scores, while the sub-items in various scopes are to distribute the different weight ratio upon its importance. The suppliers will need to conduct dialects upon exact evidence and document; in which particular merits can be proposed to evaluation team for bonus point. And lastly, the hotels which report outstanding and excellent merits upon total scores will be announced by Taipei City Department of Transportation.

Below is consolidation of items covered by the world hotel rating system stated above. In which the "hotel rating assessment system" promoted by the Tourism Bureau of MOTC will be ministered by the Tourism Bureau through a hierarchical manner, while the general hotels are ministered by various county/city governments with execution method of evaluation referring to the spirit of AAA ratings system in USA, covering both manpower and expenses to conduct the evaluation every 3 years preliminarily in terms of two stages - "architecture equipment" and "service quality", and to award 1-5 star mark to suppliers upon the evaluation outcome so as to facilitate the understanding and consumption option of overseas/domestic visitors.

\subsection{Related Literature Review of Hotel Ratings Systems}

According to a study of "advantages of operation in chain hotel operation" by Frederick (2000), the most imperative factors for the operation of those chain hotels, are standardization, management and control; According to a study of "Tracking the Critical Success Factor for Hotel Companies" by Geller (1985), a survey on the 74 managers of 27 international leisure hotels in the U.S. is conducted to further derive 7 key success factors in international leisure hotels operation, including service attitude, customer satisfaction, excellent equipment, good location, cost control, high market share and accurate market segmentation of employees.

$\mathrm{Yu}$ (1987) summarized the 9 key success factors for the hotel business based on the research result of Taiwan's tourism marketing strategy: service of service personnel, awareness, tangible products, product design, tourist source option, operating income, scale, location and number of employee at service. According to Gadotte and Turgeno (1988), service quality, food quality, employee attitude, environment cleanness, employee appearance, complaint management and price standard are key success factors; besides, Yesawich (1988) mentioned that the 9 key success factors in hotel operation in "Marketing in the 1980s": existing reputation and brand, service quality, equipment standard, uniqueness of public facility and location, convenience of room booking, location, international chain, effectiveness of marketing activity, price/value ratio perceived by customers.

According to the research result of "a comparative study of global tourism hotel management strategies among Singapore, Hong Kong and Taiwan" by Chen (1993), the operators of these 3 locations all acknowledged that the key success factors of hotel industry are service quality, ad \& promotion, location, personnel quality, equipment $\&$ décor and price. Hsieh (1998) also derived the 11 determinants to business performance in a" study of performance determinants of hotel business in Taiwan" upon regression analysis - location, time of establishment, room price, number of room, advertising expenses, number of employee, supplementary service, rating evaluated, preferential measures, number of parking space and effect of capital on business operation.

Wang (1997) pointed that the contents of hotel ratings system in Taiwan should be updated to establish a more objective, diverse and conscientious rating system to cater the trend of time and tourism industry development upon the situation of implementation of international tourism hotel education training in Taiwan, as well as the effect of external environment and internal factors inside the hotel. Su and Sun (2007) conducted construction and analysis based on the service quality assessment model proposed by Tourism Bureau in Taiwan in terms of the 5 dimensions of SERVQUAL scale, the results showed that the point of hotel service assessment inclines toward the indicators enabled by tangibility and assurance dimensions, while reliability, responsiveness and empathy are what lack and to be reinforced in the rating system of Taiwan region, the research result also pointed out that the establishment and development of hotel rating system should subject to the viewpoints of consumers, and to continuously update and foster the acceptance and confidence of consumers on hotel ratings system and to keep pace with the times. 
According to a study of criteria for judgment of luxury hotels in Taiwan and Macao by Hung (2008), an emphasis is placed on developing the benchmark structure to judge the luxury recreation hotels from service contents, equipment contents, business management and customer driven dimensions, the result also indicated that "business management" and "customer driven" dimensions are the highlights generally acknowledged by scholars from the industry and government in Taiwan and Macao for tourists to judge the luxury hotels.

Currently, there has no related studies domestically or abroad in terms of re-establishment of hotel rating system, while most studies focused on exploring the current overall situation development and related flaws of hotel rating system, with customer-oriented viewpoint added (Butcher, Beverley \& Frances, 2002; Mattila, 1999; Narver \& Slater, 1990; Su \& Sun, 2007; Susskind, Kacmar \& Borchgrevink, 2007), or a necessary combination of software and hardware indicators for hotel assessment (Mattila, 1999; Paraskevas, 2001; Susskind et al., 2007), in which an assessment on hardware cannot be proceeded independently, or, it will be a meaningless evaluation design.

\subsection{Organization Structure of Hotel Industry}

The organization structure of hotels will be varied by business characteristics, size, division of labor by various departments caused by whether to join the chain system, but in general, the process of overall hotel organization can be divided into two parts: from for house and back of the house (Wu, 2008), in which "from for house" refers to "business units" of hotel business with mission to cover comfortable and satisfactory accommodation facility, equipment and other service related contents provided to visitors, including concierge, cashier, lobby, business center, room service, restaurant and other supplementary public facility.

The nature of "from for house" is similar to the "primary activity" of value chain in if looking from the perspective of value chain by porter (1985), furthermore, the matters managed by "from for house" of hotels are routine oriented, therefore, the study has initially named the related job descriptions and procedure of "from for house" as "primary routine activity" dimension, The "back of the house" refers to the "management units" of hotel business and is responsible for the back-office mission, and is therefore, called "heart of hotel", in which the department is responsible for related aim. and support inside the hotel, to properly provide tourists with various service skills and training under a principle of mutual division of labor, real-time support, is devoted to creating a psychological feeling of making themselves at home and accommodation value; including business management, HR, training, finance \& accounting, general affairs, merchandising and engineering affairs, in the meantime, covering external advertising and marketing, professional training to service personnel. Furthermore, the duty that the "back of the house" is responsible for is trendy, variant and supportive tasks oriented.

According to the suggestions of above stated research conclusions, the study will firstly consolidate related literatures of operating performance of a successful hotel and then combine with the highlights of existing thinking stereotype that the research plan expects to break through: addition of customer perspective combined with hardware/software facility (equipment) as well as organization structure of hotel business, to re-divide the primary dimensions of tier-1 hotel ratings system as service assurance, service responsiveness, service tangibility and service empathy dimensions in terms of SERVQUAL's dimensions by Parasuraman et al. (1985), and to develop "hierarchical hotel rating system" upon various items of architecture equipment and service quality assessment benchmark covered by "hotel ratings system" which implemented by Tourism Bureau of MOTC in terms of these 4 dimensions (Figure 1).

\section{Research Methodology}

\subsection{Research Framework}

The primary purpose of this study is to establish overall hierarchical structure of hotel rating system. Therefore, it will be conducted through a consolidation of documents of domestic/overseas hotel rating systems, situation of hotel operation in Taiwan and secondary data of direction for future development combined with the a hierarchical design concept of "hotel rating system" proposed by Taipei City Department of Transportation to draft a preliminary hierarchical structure of "establishment of hotel ratings system" as the basis of questionnaire design by Fuzzy Delphi Method and a reference to the selection of assessment items, so as to facilitate the process of subsequent empirical study.

\subsection{Fuzzy Delphi Method}

The fuzzy theory was proposed by Zadeh (1965) at the university of California at Berkeley. Dr. Zadeh was of the opinion that the traditional scientific methods often ignored the uncertainty and ambiguous existence of human life, so he set out to use fuzzy sets theory and adopt the fuzzy logical concepts to process. Then Buckley (1985) incorporated the fuzzy set theory into the traditional AHP, FAHP thus became a suitable tool for solving real-world multi-criteria decision- making (MCDM) problems (Buyukozkan, Kahraman \& Ruan, 2004). 
This study introduces the fuzzy theory into the Delphi method by integrating with the points of view of many scholars, including Hsu (1998) and Chen (2001). In order to improve the problems faced by the traditional Delphi method, this study has used the bi-triangular fuzzy arithmetic to integrate the advice of experts and has then tested the convergence effect recognized by experts that refers to the "gray zone test method". The fuzzy Delphi method is established by means of the following steps.

\subsection{Fuzzy Analytic Hierarchy Process (FAHP)}

In incorporating the Fuzzy Theory into the Analytic Hierarchy Process developed by Saaty (1980), we assess the weight attached to various assessment criteria and sort out their importance through which more objective and reasonable key success factors could be induced. This analytical process combines the concepts of several scholars, including Buckley (1985), Robbins (1994), Hsu (1998), and Chen (2002) and has the advantage in that experts need to fill in only one definite value when making paired comparisons, without falling into the dilemma of not knowing how to specify the fuzzy number or the need to understand its definitions.

\subsection{Construct the Questionnaire of Hotel Rating System}

\subsubsection{First and the Second Stage Questionnaire Design}

The first stage of questionnaire design was based on the above primary hierarchy framework and utilized fuzzy Delphi questionnaire to assess each measurement concept and evaluation criteria. This questionnaire comprised three parts, including questionnaire instruction, questionnaire content and basis data. Furthermore, all the criteria were measured using a scale ranging from zero to 10 , with the higher grades indicating the higher importance. On the other hand, each criterion must complete an acceptance scope and single value of importance level. The questionnaire also provided a space for experts to express their professional opinions and assign a total grade for each concept.

\subsubsection{Research Objects}

The study introduces expert questionnaire by two stages as a basis for data judgment of analysis. The experts who answer the questionnaire are limited to experts who specifically focus on tourism study or scholars from the academy and government who engage in leisure hotels \& resorts field, those who are interested in the issues and contents of the study and are willing to answer the questionnaire will be the top priority for investigation. According to Robbins (1994), a scale of 5-7 experts suits best for a process of group decision making, therefore, the expert questionnaire will be distributed in terms of a more objective and accurate manner.

Given a fact that the expert opinions will be consolidated with Fuzzy Delphi Method and FAHP introduced to construct a hotel ratings system of expert consensus, order of importance and weight relation. The study will therefore, focus on the 90 international tourism hotels and general hotel suppliers in Taiwan announced by Tourism Bureau of MOTC (Executive Information System of Tourism Bureau, MOTC, 2008); as well as the central and local governments and responsible persons of civic groups with regard to tourism \& travel industry, with scholars who report professional insights on hotel assessment issues from academic units, to establish the optimal system and guideline to the hotel assessment in Taiwan by consolidating the opinions and communicating with experts from industry/government/academy circles.

\section{Empirical Data Analysis of Key Indicators Establishment for the Hotel Assessment in Taiwan}

\subsection{Result of Empirical Data Analysis}

4.1.1 Questionnaire Analysis by Fuzzy Delphi Method in Stage 1-Establish a Hierarchical Structure upon Expert Consensus

The study has firstly conducted literature review and consolidation of primary data, to draft preliminary hierarchical structure strategically, and to consolidate the expert opinions through an expert questionnaire survey by Fuzzy Delphi Method, with the optimal and considerably important judgment benchmark selected afterwards which is regard as an importance base to subsequently establish a hierarchical structure by FAHP.

\subsubsection{Condition of Distribution and Return of Questionnaire}

The expert questionnaire is conducted on the experts from the industry/academy/government in tourism \& leisure field in the first stage of the study, which is distributed between Mar. 1, 2010 and Mar. 31, 2010. The research team firstly drafted a list of scholars from the industry/government during Dec. 2009 to Jan. 31, 2010, to liaise with respondents in terms of the research background and purpose of this expert questionnaire from one to one, the expert questionnaire enclosed with stamped envelope will be mailed to the address appointed by the respondent if the other side agrees to answer willingly. There are 50 expert questionnaires by Fuzzy Delphi Method distributed in stage 1, with 41 questionnaires returned and 34 valid questionnaires, reporting a $68 \%$ rate of return, in which 9 are from 
government, 16 from suppliers and 9 from scholars.

\subsubsection{Filter the Hotel Evaluation Criteria}

This investigation applied the method of Lee, Lu, San and Hsu (2006) who designed an EXCEL program based on the fuzzy Delphi operation model and the statistical software - EXCEL Expert Choice 2000 to calculate the relative number. First, this study utilized the "bi-triangle fuzzy number" to identify evaluation criteria, and then analyzed the received completed.

Step 1: Each expert gave a potential interval-value aimed at every criteria item. The minimum interval-value means "the most conservative perceived values" from all experts' evaluated each one's quantification fraction. On the contrary, the maximum interval-value means "the most optimistic perceived values" from all experts.

Step 2: Then, it aimed to analysis "the most conservative perceived values" and "the most optimistic perceived values" of each criteria item ( $i$ ) from all experts. The observation value might be cast if it fell on twice of standard deviation. After that, it got the minimum value $C_{L}^{i}$, geometric mean $C_{M}^{i}$, the maximum value $C_{U}^{i}$ from "the most conservative perceived values", and got the minimum value $O_{L}^{i}$, geometric mean $O_{M}^{i}$, the maximum value $O_{U}^{i}$ from "the most optimistic perceived values".

Step 3: Bases on upon step, it might set triangular fuzzy number $C^{i}=\left(C_{L}^{i}, C_{M}^{i}, C_{U}^{i}\right)$ of "the most conservative perceived value" and $O^{i}=\left(O_{L}^{i}, O_{M}^{i}, O_{U}^{i}\right)$ of "the most optimistic perceived value" from each criteria item.

Step 4: Finally, it precedes the following methods to test the level of all experts' common consensus.

- If $C_{U}^{i} \leq O_{L}^{i}$, it means there are no overlap phenomenon in bi-triangular fuzzy number. Furthermore, it also expresses all experts' suggestions possessed common consensus. For this reason, it makes the "important level value of common consensus $\left(\mathrm{G}^{i}\right)$ " equal to the arithmetic mean from $C_{M}^{i}$ to $O_{M}^{i}$, and uses $\mathrm{G}^{\mathrm{i}}=\frac{C_{M}^{i}+O_{M}^{i}}{2}$ to calculate.

- If $C_{U}^{i}>O_{L}^{i}$, it shows an overlap phenomenon in bi-triangular fuzzy number. Furthermore, the grey-region of fuzzy relationship express like $\mathrm{Z}^{\mathrm{i}}=C_{U}^{i}-O_{L}^{i} \leqq \mathrm{M}^{\mathrm{i}}=O_{M}^{i}-C_{M}^{i}$. Although there exists fuzzy section, but the extreme value not exceeds too much than the other expert's suggestions to cause discrepancy and emanation.

- If $C_{U}^{i}>O_{L}^{i}$, it shows an obviously overlap phenomenon in bi-triangular fuzzy number. As well as the grey-region of fuzzy relationship express as $Z^{\mathrm{i}}=C_{U}^{i}-O_{L}^{i} \geqq \mathrm{M}^{\mathrm{i}}=O_{M}^{i}-C_{M}^{i}$. Moreover, it means each expert's suggestion accounts an uncommon conscious region. So, it might supply these undiscrepancy data to all experts and repeats foregoing steps until it figured out $\mathrm{G}^{i}$.

Step 5: Bases on step 4, it calculates $G^{i}$ from each criterion. The higher $G^{i}$ value means the higher common conscious level of experts. After all, it uses the most possible geometric mean from each criterion to get arithmetic mean (the threshold value in this investigation).

This study obtained a threshold value of 7.9, and also expressed that if the value of $\mathrm{G}^{i}$ from all criterion exceeding 7.9 is reserved rather than being deleted. Finally, the result is the deletion of 8 evaluation criteria and the retention of 25 (effective ratio is $68 \%$ ) (Table 1 and Figure 2). Moreover, this study uses Figure 2 to design the second stage expert questionnaire, and provides that questionnaire to managers, officials and scholars involved in tourism. Subjects then evaluate the relative importance of the various evaluation criteria. Finally, this study determines the relative weights of the various criteria by applying FAHP to identify real evaluation criteria in the hotel rating system in Taiwan.

\subsection{The Questionnaire Analysis by FAHP in Stage 2-Selects and Establishes the Hotel Assessment Indicator System in Taiwan}

According to the aforementioned 17 assessment indicators selected upon expert consensus by Fuzzy Delphi Method in stage 1, the questionnaire in stage 2 of hierarchical structure is designed by AFHP as Figure 2.

The $2^{\text {nd }}$ stage will introduce FAHP on the valid questionnaires to establish fuzzy inverse matrix value, with consistency test introduced to calculate the C.I. value (consistency indicator) and C.R. value (consistency ratio) of expert questionnaire in this stage to determine degree of consistency in this matrix, and to respectively calculate the fuzzy weight value of evaluation guidelines and weighted value after regulation between various dimensions and inside the dimension. Besides, calculation of key figure will be conducted by AHP using Expert Choice 2003 
software.

\subsubsection{Condition of Questionnaire Distribution and Return}

The duration of expert questionnaire in stage 2 is between May 1, 2010 and June 20, 2010, which subjects to the same respondents of scholars from the industry/government in stage 1, totaling 41 questionnaires by Fuzzy Delphi Method distributed in stage 2, reporting 38 questionnaires returned and 29 valid questionnaires, and a $70.7 \%$ rate of return, in which 7 of them are from government, 14 from suppliers and 8 from scholars.

\subsection{Hierarchical Weight Analysis of Hotel Ratings System in Various Dimensions}

\subsubsection{Hierarchical Weight Analysis of Primary Dimensions}

The primary dimensions of this study include service assurance, service responsiveness, service tangibility and service empathy dimensions, with triangular fuzzy number introduced firstly to establish a positive reciprocal matrix (Table 2) as a basis for the calculation of fuzzy weight value (Table 3), and to conduct consistency test of fuzzy weight value upon the crisp value given by the scholars from the industry/government/academy on the expert questionnaire.

According to Table 2 listed above, the consistency index C.I. $=0.04$ and C.R. $=0.04$ of primary dimensions all conform to the acceptable error range of C.R. $\leqq 0.1$, therefore the judgment by expert opinion in this hierarchy before and after is consistent, and according to the result of weight analysis of hotel assessment in Taiwan upon the 4 indicator dimensions in Table 3, the weight value by order of importance is as service assurance $(29.7 \%)$, service empathy (21.2\%), and lastly, the service responsiveness (20.4\%).

\subsection{A Discussion of Key Indicators for Hotel Assessment in Taiwan}

The consistency ratio hierarchy (C.R.H.) of establishing key indicators for hotel assessment in Taiwan is 0.051, which conforms to a standard range of C.R.H $<0.1$, indicating that the hierarchical structure established by the study shows an optimal arrangement in terms of association between various judgment benchmarks, therefore the consistency of overall architecture model is acceptable.

Lastly, the study will follow the relative comparison weight (local priority) enabled by the judgment benchmark in various dimensions, to further calculate the global priority in overall, so as to understand the weight ratio comprised by various assessment criteria in overall architecture, to prioritize the various judgment benchmarks by absolute weight value and importance, and to further select and establish key indicators for the hotel assessment in Taiwan.

The study will consider Daniel (1961) point of view - the operation outcomes of most industry operation will subject to the most imperative 3-6 indicators, therefore the first assessment criteria listed in table 4 will be selected as key indicators for the establishment of hotel assessment in Taiwan, which are (1) service personnel to describe various service facilities and regulations of the hotel as detail as possible; (2) service personnel to exactly repeat the complete contents of to-do-items assigned by tourists; (3) service personnel to actively provide efficient service; (4) space planning and smooth movement inside and outside the hotel; (5) the geographic location and traffic convenience of hotel and (6) excellent garden and landscape design in hotel.

\section{Conclusion and Suggestions}

\subsection{Conclusion}

An attention on leisure consciousness and related activities by Taiwan people also signifies an enhanced standard on service quality and demand satisfaction of tourism \& leisure industry, in which a perception of customer satisfaction perceived by consumers in terms of appraisal dimension and measurement was gradually replaced by intangible accommodation experience or personalized service by service personnel from tangible hardware facilities and equipments in the past. The study follows the assessment standards of "star hotel rating system" promoted and implemented by Tourism Bureau, Ministry of Transportation and Communications (MOTC) in 2010, to conduct analysis in terms of SERVQUAL's five dimensions proposed by Parasuraman et al. (1985). According to the research results, the hotel rating system in Taiwan is badly in need of an attention to the establishment and assessment of indicators in terms of "service assurance" and "service empathy" dimensions, the results also indicated that tourists make judgment based on "tangible hardware" along with "intangible service" provided by the hotels, are important determinants to enable a differentiation. Therefore, the service, equipment, fundamental the necessary contents that the hotel suppliers emphasize on should be conducted through various methods of business operations, which to be effectively delivered in terms of a manner expected by the customer, and to head toward a direction of establishing a positive feeling of customer on travel and experience enhancement, in which the details and scope covered by hotel business are expansive, it is difficult to effectively deliver the connotation of "customer driven" service mission conveyed through visitors' beautiful experience if there has no systematic management and 
development of employees who report centripetal force, responsibility and organizational citizenship behaviors. And as a result, service assurance and service empathy are the highlights of the first importance that the hotel industry in Taiwan should emphasize on.

In fact, the 4 major dimensions for the hotel assessment in Taiwan that the study establish are similar to the I-P-O (input-process-output) model of business management theory, which effectively combines with the software/hardware (service and equipment contents) that the hotel business should cover; including service procedure with meticulous care, top/unique and exclusive facilities, equipment and effective design of supplementary goods through a comprehensive business management system and customer oriented philosophy, to adjust and react upon external/internal environment, to satisfy different consumption needs of visitors or create excellent accommodation experience of visitors, to foster the positive idea of consumption inside the consumers and focus on the ultimate goal of overall business performance.

\subsection{Suggestions}

Tourism industry actually reports shorter time of development, in which it lacks a consensus on related theories and thread of thoughts and is an immature field, therefore, related studies and discussions on hotel assessment are rare and little. Tourism industry is one of the important national policies for countries to develop the economy and global awareness, in which various countries should focus on the investment of tourism \& leisure industry and plans in related manpower quality developments, and follow the development trend of global tourism market to adjust business strategies and establish competitive advantages, therefore the study suggests the scholars from the industry/government to focus on subsequent assessment ratings of tourism \& leisure related industries, to propose a more insightful opinion and related empirical findings of this prospective and potential industry.

Establish a reference to the overall assessment indicators of tourism \& leisure related industries, related measurement items and critical values, it is truly an urgent matter of immediacy and necessity to establishing the government policy for world tourism industry and the business goals for enterprises, this is an important foundation stone to enable a more mature, diverse and continuous upward enhancement of tourism \& leisure field.

\section{Acknowledgement}

This research is sponsored by the National Science Council (NSC 98-2410-H-324-014-).

\section{References}

Buckley, J. J. (1985). Fuzzy hierarchical analysis. fuzzy sets and systems, 17, 233-247. http://dx.doi.org/10.1016/0165-0114(85)90090-9

Butcher, K., Beverley, S., \& Frances, C. (2002). Effect of social influence on repurchase intentions. The Journal of Services Marketing, 16(6), 503-514. http://dx.doi.org/10.1108/08876040210443382

Buyukozkan, G., Kahraman, C., \& Ruan, D. (2004). A fuzzy multi-criteria decision approach for software development strategy selection. International Journal of General Systems, 33(2-3), 259-280. http://dx.doi.org/10.1080/03081070310001633581

Chen, J. H. (2002). Venture capital companies investing high-tech industry by fuzzy multi-criteria methods: Biology industry as example. Fu Jen Management Review, 9(2), 87-109.

Frederick, N. (2000). Loyalty: Customer relationship management in the new era of internet marketing. New York: McGraw-Hill.

Geller, A. N. (1985). The Ernst and young guide to performance measurement for financial institution. IL: Richard D, Irwin, Inc.

Hsieh, A. (1998). The Study of the Effects of Loading Business Performance in Taiwan (Master Thesis). Da-Yeh University.

Hsu, T. H. (1998). The fuzzy delphi analytic hierarchy process. Journal of the Chinese Fuzzy Systems Association, 4(1), 59-72.

Hung, J. Y. (2008). The Research of the Determinative Criteria and Consumer Cognition on Brand Equity of the Luxury Leisure Hotel: Taiwan and Macau (Doctor Thesis). Chang-Jang Christian University.

Kim, B. Y., \& Oh, H. (2004). How do hotel obtain a competitive advantages?. International Journal of Contemporary Hospitality Management, 16(1), 65-71. http://dx.doi.org/10.1108/09596110410516589

Lee, M. S., Lu, S. I., San, Y. H., \& Hsu, Y. C. (2006). The study of key success factors for cross-domain transformation of agricultural biotechnology industry in Taiwan-Applying view of value chain. Journal for SME 
Development, 2, 53-87.

Lewis, R. C. (1989). Hospitality marketing: The internal approach. Cornell Hospitality and Restaurant Administration Quarterly, 30(3), 41-45.

Mattila, A. (1999). Consumers' value judgments. Cornell Hospitality and Restaurant Administration Quarterly, 40(1), 40-46. http://dx.doi.org/10.1177/001088049904000121

Narver, J. C., \& Slater, S. F. (1990). The effect of a market orientation on business profitability. Journal of Marketing, 54, 20-35. http://dx.doi.org/10.2307/1251757

Paraskevas, A. (2001). Internal service encounters in hotels: An empirical study. International Journal of Contemporary Hospitality Management, 13(6), 285-292. http://dx.doi.org/10.1108/09596110110400481

Parasuraman, A., Zeithaml, V. A., \& Berry, L. L. (1985). A conceptual model of service quality and its implication for future research. Journal of Marketing, 49(Fall), 41-50. http://dx.doi.org/10.2307/1251430

Porter, M. E. (1985). Competitive Strategy. New York: Free Press. http:dx.doi.org/10.1108/09596110110400481

Robbins, S. P. (1994). Management. New Jersey: Prentice-Hall.

Satty, T. L. (1980). The analytic hierarchy process. New York: Mc Graw-Hill.

Sparks, B., Butcher, K., \& Pan, G. (2007). Understanding customer-derived value in the timeshare industry. Cornell Hotel and Restaurant Administration Quarterly, 48(1), 28-45. http:dx.doi.org/10.1177/0010880406294473

$\mathrm{Su}$, C. S., \& Sun, L. H. (2007). Taiwan's hotel rating system. Cornell Hotel and Reataurant Administration Quarterly, 48(4), 392-401. http:dx.doi.org/10.1177/0010880407305836

Susskind, A. M., Kacmar, K. M., \& Borchgrevink, C. P. (2007). How organizational standards and coworker support improve restaurant service. Cornell Hospitality and Restaurant Administration Quarterly, 48(4), 370-379. http:dx.doi.org/10.1177/0010880407300158

Wang, H. H. (1997). The Study of the International Tourist Hotel Training Practice in Taiwan (Master Thesis). National Dong-Hwa University.

Yesawich, P. C. (1988). Marketing in the 1980s. Cornell Hospitality and Restaurant Administration Quarterly, 28(4), 38-45.

Yu, S. H. (1987). The study of marketing strategies in Taiwan tourist hotels (Master Thesis). Chung Yuan Christian University.

Zadeh, L. (1965). Fuzzy Sets. Information and Control, 8(3), 338-353. http://dx.doi.org/10.1016/S0019-9958(65)90241-X 
Table 1. Analytic Table of Fuzzy Delphi Questionnaire

\begin{tabular}{|c|c|c|c|c|c|c|c|c|c|c|c|c|}
\hline Concept & evaluation criteria & \multicolumn{3}{|c|}{$\begin{array}{c}\text { the most } \\
\text { optimistic } \\
\text { perceived values } \\
\left(O_{L}^{i}, O_{M}^{i}, O_{U}^{i}\right)\end{array}$} & \multicolumn{3}{|c|}{$\begin{array}{c}\text { the most } \\
\text { conservative } \\
\text { perceived values } \\
\left(C_{L}^{i}, C_{M}^{i}, C_{U}^{i}\right)\end{array}$} & \multirow{2}{*}{$\begin{array}{c}\begin{array}{c}\text { Geometric } \\
\text { mean }\end{array} \\
8.4\end{array}$} & \multirow{2}{*}{$\begin{array}{l}\mathrm{M}^{\mathrm{i}} \\
2.5\end{array}$} & \multirow{2}{*}{$\begin{array}{c}Z^{\mathrm{i}} \\
0\end{array}$} & \multirow{2}{*}{$\begin{array}{c}\text { Interval } \\
\text { value of } \\
\text { expert } \\
\text { opinion }\end{array}$} & \multirow{2}{*}{$\begin{array}{r}\mathrm{G}^{\mathrm{i}} \\
8.1 \\
\end{array}$} \\
\hline \multirow{11}{*}{$\begin{array}{c}\text { Service } \\
\text { assurance }\end{array}$} & $\begin{array}{l}\text { Excellent garden and landscape design } \\
\text { overall in hotel }\end{array}$ & 8 & 9.4 & 10 & 5 & 6.9 & 8 & & & & & \\
\hline & $\begin{array}{l}\text { Hotel environment cleanness and } \\
\text { maintenance }\end{array}$ & 9 & 9.7 & 10 & 6 & 6.9 & 8 & 8.4 & 2.8 & -1 & ○ & 8.3 \\
\hline & $\begin{array}{l}\text { Proper arrangement of public areas in } \\
\text { hotel }^{*}\end{array}$ & 7 & 9.3 & 10 & 4 & 6.1 & 8 & 8.1 & 3.2 & 1 & $\star$ & 7.6 \\
\hline & $\begin{array}{l}\text { Clear and easy-to-understand hotel } \\
\text { marks in various types }\end{array}$ & 9 & 9.7 & 10 & 4 & 6.3 & 8 & 7.9 & 3.4 & -1 & ○ & 8.0 \\
\hline & $\begin{array}{l}\text { Diverse thoughtful tourism (business) } \\
\text { centers in hotel }\end{array}$ & 7 & 9.2 & 10 & 3 & 6.1 & 7 & 7.6 & 3.1 & 0 & o & 7.7 \\
\hline & $\begin{array}{l}\text { Excellent parking space management } \\
\text { in hotel }\end{array}$ & 9 & 9.8 & 10 & 5 & 6.9 & 8 & 8.6 & 2.9 & -1 & o & 8.3 \\
\hline & $\begin{array}{l}\text { Comprehensive and complete banquet } \\
\text { facilities }\end{array}$ & 9 & 9.7 & 10 & 5 & 6.6 & 8 & 8.3 & 3.1 & -1 & ○ & 8.2 \\
\hline & $\begin{array}{l}\text { Familiarity of service personnel with } \\
\text { hotel's telephone exchange service }^{*}\end{array}$ & 8 & 9.6 & 10 & 4 & 7.2 & 9 & 8.1 & 3.2 & 1 & $\star$ & 8.4 \\
\hline & $\begin{array}{l}\text { Ability of service personnel to } \\
\text { describe service facilities and } \\
\text { regulations in hotel }\end{array}$ & 9 & 9.7 & 10 & 3 & 6.3 & 7 & 8.0 & 3.3 & -2 & o & 8.0 \\
\hline & $\begin{array}{l}\text { Service personnel can complete finish } \\
\text { the tourists' contents of the action } \\
\text { items }\end{array}$ & 9 & 9.7 & 10 & 3 & 6.4 & 8 & 8.3 & 3.3 & -1 & ○ & 8.1 \\
\hline & $\begin{array}{l}\text { Service personnel can clear record of } \\
\text { tourists' information and archiving }\end{array}$ & 8 & 9.4 & 10 & 5 & 6.6 & 8 & 8.3 & 3.0 & 0 & o & 8.0 \\
\hline \multirow{3}{*}{$\begin{array}{l}\text { Service } \\
\text { responsive- } \\
\text { ness }\end{array}$} & $\begin{array}{l}\text { Excellent fire fighting equipment and } \\
\text { harmonious space design at hotels }\end{array}$ & 7 & 9.1 & 10 & 3 & 6.2 & 8 & 7.6 & 2.9 & 1 & $\star$ & 7.5 \\
\hline & Equipment adequate escape & 9 & 9.8 & 10 & 3 & 6.3 & 9 & 7.8 & 3.5 & 0 & ○ & 8.1 \\
\hline & $\begin{array}{l}\text { Hotel promote the concept of green } \\
\text { building green }\end{array}$ & 9 & 9.7 & 10 & 5 & 6.3 & 8 & 7.9 & 3.4 & -1 & ○ & 8.0 \\
\hline \multirow{7}{*}{$\begin{array}{l}\text { Service } \\
\text { tangibility }\end{array}$} & $\begin{array}{l}\text { Stylish building appearance merged } \\
\text { with the environment }\end{array}$ & 8 & 9.6 & 10 & 5 & 6.6 & 8 & 8.1 & 3.0 & 0 & $\circ$ & 8.1 \\
\hline & $\begin{array}{l}\text { Space planning and smooth movement } \\
\text { inside and outside the hotel }\end{array}$ & 9 & 9.7 & 10 & 3 & 6.4 & 8 & 8.3 & 3.3 & -1 & ० & 8.1 \\
\hline & $\begin{array}{l}\text { Geographic location and traffic } \\
\text { convenience of hotel }\end{array}$ & 8 & 9.6 & 10 & 5 & 6.7 & 8 & 8.3 & 2.8 & 0 & ○ & 8.2 \\
\hline & $\begin{array}{l}\text { Excellent garden landscape design at } \\
\text { hotels }^{*}\end{array}$ & 7 & 9.3 & 10 & 2 & 5.6 & 7 & 7.4 & 3.6 & 0 & 0 & 7.4 \\
\hline & $\begin{array}{l}\text { Exquisite and beautiful restaurant and } \\
\text { banquet facilities in hotel }\end{array}$ & 7 & 8.9 & 10 & 2 & 5.4 & 7 & 6.8 & 3.5 & 0 & 0 & 7.2 \\
\hline & $\begin{array}{l}\text { Diverse sports facility and complete } \\
\text { maintenance }\end{array}$ & 8 & 9.5 & 10 & 5 & 6.8 & 8 & 8.3 & 2.7 & 0 & ○ & 8.1 \\
\hline & Practical and stylish room equipments ${ }^{*}$ & 8 & 9.2 & 10 & 4 & 6.1 & 8 & 7.7 & 3.1 & 0 & $\circ$ & 7.7 \\
\hline \multirow{4}{*}{$\begin{array}{l}\text { Service } \\
\text { empathy }\end{array}$} & $\begin{array}{l}\text { Excellent sound insulation effect } \\
\text { between space and the tranquility } \\
\text { inside the hotel }\end{array}$ & 8 & 9.6 & 10 & 5 & 6.6 & 8 & 8.1 & 3.0 & 0 & 0 & 8.1 \\
\hline & $\begin{array}{l}\text { Kind attitude and proper presence of } \\
\text { service personnel }\end{array}$ & 8 & 9.4 & 10 & 5 & 6.9 & 8 & 8.4 & 2.5 & 0 & O & 8.1 \\
\hline & $\begin{array}{l}\text { Active attitude of service personnel } \\
\text { who provide efficient service }\end{array}$ & 8 & 9.5 & 10 & 5 & 6.5 & 7 & 8.2 & 3.0 & -1 & ○ & 8.0 \\
\hline & $\begin{array}{l}\text { Rich contents and practical service } \\
\text { web system installed by the hotel }\end{array}$ & 8 & 9.4 & 10 & 5 & 6.1 & 7 & 7.8 & 3.2 & -1 & 0 & 7.7 \\
\hline & $\mathrm{G}^{\mathrm{i}}$ & \multicolumn{11}{|c|}{7.9} \\
\hline
\end{tabular}

Note: $\circ$ indicates $C_{U}^{i} \leq O_{L}^{i}$ that experts' opinions in the consensus section, and utilized $\mathrm{G}^{\mathrm{i}}=\left(\mathrm{C}_{\mathrm{M}}^{\mathrm{i}}+\mathrm{O}_{\mathrm{M}}^{\mathrm{i}}\right) / 2$ to calculate.

$\star$ indicates $C_{U}^{i}>O_{L}^{i}$, and $Z^{i}=C_{U}^{i}-O_{L}^{i} \leqq M^{i}=O_{M}^{i}-C_{M}^{i}$. It calculates fuzzy set by min and get $G^{i}$.

${ }^{*}$ indicates the evaluation criteria be delete. 
Table 2. The Consistency Test on the Main Concept in the Indicators Establishment for the Hotel Assessment in Taiwan

\begin{tabular}{|l|l|l|l|l|}
\hline fuzzy inverted value matrix \\
\hline concept & service assurance & service responsiveness & service tangibility & service empathy \\
\hline service assurance & $(1.00,1.00,1.00)$ & $(0.11,0.45,7.71)$ & $(0.25,4.00,9.00)$ & $(0.17,2.65,9.00)$ \\
\hline service responsiveness & $(0.13,2.31,9.00)$ & $(1.00,1.00,1.00)$ & $(0.25,4.01,9.00)$ & $(0.17,2.65,9.00)$ \\
\hline service tangibility & $(0.13,0.53,7.21)$ & $(0.11,0.31,4.00)$ & $(1.00,1.00,1.00)$ & $(0.13,0.72,5.00)$ \\
\hline service empathy & $(0.13,0.88,7.14)$ & $(0.11,0.38,5.90)$ & $(0.21,1.37,7.72)$ & $(1.00,1.00,1.00)$ \\
\hline$\lambda_{\max }=4.11 \quad$ C.I. $=0.04 \quad$ C.R. $=0.04$ \\
\hline
\end{tabular}

Table 3. Main Concepts of the Weight Analysis in the Indicators Establishment for the Hotel Assessment in Taiwan

\begin{tabular}{llllll}
\hline concept & $\mathrm{W}_{\mathrm{ai}}$ & $\mathrm{W}_{\delta \mathrm{i}}$ & $\mathrm{W}_{\gamma \mathrm{i}}$ & Normalized weights & Importance order \\
\hline service assurance & 0.010 & 0.331 & 5.712 & 0.297 & 1 \\
service responsiveness & 0.008 & 0.092 & 4.012 & 0.204 & 4 \\
service tangibility & 0.008 & 0.162 & 5.221 & 0.287 & 2 \\
service empathy & 0.009 & 0.123 & 4.534 & 0.212 & 3 \\
\hline
\end{tabular}

Table 4. Overall Assessment of the Results in the Key Indicators Establishment for the Hotel Assessment in Taiwan

\begin{tabular}{|c|c|c|c|c|c|}
\hline Main concept & $\begin{array}{l}\text { Weight on } \\
\text { concept }\end{array}$ & Evaluation criteria & $\begin{array}{l}\text { Hierarchy } \\
\text { weight }\end{array}$ & $\begin{array}{l}\text { Absolutely } \\
\text { weight }\end{array}$ & $\begin{array}{l}\text { Importance } \\
\text { ranking }\end{array}$ \\
\hline \multirow{8}{*}{$\begin{array}{l}\text { Service } \\
\text { assurance }\end{array}$} & \multirow{8}{*}{$\begin{array}{l}0.297 \\
(1)\end{array}$} & $\begin{array}{l}\text { Excellent garden and landscape design overall in } \\
\text { hotel }\end{array}$ & 0.270 & 0.064 & 6 \\
\hline & & Hotel environment cleanness and maintenance & 0.151 & 0.036 & 14 \\
\hline & & $\begin{array}{l}\text { Clear and easy-to-understand hotel marks in various } \\
\text { types }\end{array}$ & 0.268 & 0.064 & 7 \\
\hline & & Excellent parking space management in hotel & 0.204 & 0.060 & 15 \\
\hline & & Comprehensive and complete banquet facilities & 0.166 & 0.039 & 9 \\
\hline & & $\begin{array}{l}\text { Ability of service personnel to describe service } \\
\text { facilities and regulations in hotel }\end{array}$ & 0.338 & 0.091 & 1 \\
\hline & & $\begin{array}{l}\text { Service personnel can complete finish the tourists' } \\
\text { contents of the action items }\end{array}$ & 0.333 & 0.089 & 2 \\
\hline & & $\begin{array}{l}\text { Service personnel can clear record of tourists' } \\
\text { information and archiving }\end{array}$ & 0.185 & 0.024 & 12 \\
\hline \multirow{2}{*}{$\begin{array}{l}\text { Service } \\
\text { responsiveness }\end{array}$} & \multirow{2}{*}{$\begin{array}{l}0.204 \\
(4)\end{array}$} & Equipment adequate escape & 0.105 & 0.029 & 17 \\
\hline & & Hotel promote the concept of green building green & 0.157 & 0.033 & 10 \\
\hline \multirow{4}{*}{$\begin{array}{l}\text { Service } \\
\text { tangibility }\end{array}$} & \multirow{4}{*}{$\begin{array}{l}0.287 \\
(2)\end{array}$} & $\begin{array}{l}\text { Stylish building appearance merged with the } \\
\text { environment }\end{array}$ & 0.245 & 0.051 & 8 \\
\hline & & $\begin{array}{l}\text { Space planning and smooth movement inside and } \\
\text { outside the hotel }\end{array}$ & 0.297 & 0.087 & 4 \\
\hline & & Geographic location and traffic convenience of hotel & 0.287 & 0.084 & 5 \\
\hline & & Diverse sports facility and complete maintenance & 0.141 & 0.018 & 13 \\
\hline \multirow{3}{*}{$\begin{array}{l}\text { Service } \\
\text { empathy }\end{array}$} & \multirow{3}{*}{$\begin{array}{l}0.212 \\
(3)\end{array}$} & $\begin{array}{l}\text { Excellent sound insulation effect between space and } \\
\text { the tranquility inside the hotel }\end{array}$ & 0.143 & 0.034 & 16 \\
\hline & & $\begin{array}{l}\text { Kind attitude and proper presence of service } \\
\text { personnel }\end{array}$ & 0.157 & 0.037 & 11 \\
\hline & & $\begin{array}{l}\text { Active attitude of service personnel who provide } \\
\text { efficient service }\end{array}$ & 0.329 & 0.088 & 3 \\
\hline
\end{tabular}




\begin{tabular}{|c|c|c|}
\hline \multirow{6}{*}{ 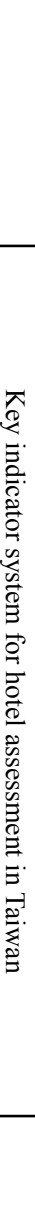 } & \multirow{2}{*}{$\begin{array}{c}\text { Service } \\
\text { assurance }\end{array}$} & \multirow{3}{*}{$\begin{array}{l}\text { 1. Excellent garden and landscape design } 2 . \text { overall in hotel } \\
\text { 2. Hotel environment cleanness and maintenance } \\
\text { 3. Proper arrangement of public areas in hotel } \\
\text { 4. Clear and easy-to-understand hotel marks in various types } \\
\text { 5. Diverse thoughtful tourism (business) centers in hotel } \\
\text { 6. Excellent parking space management in hotel } \\
\text { 7. Comprehensive and complete banquet facilities } \\
\text { 8. Familiarity of service personnel with hotel's telephone exchange service } \\
\text { 9. Ability of service personnel to describe service facilities and regulations in hotel } \\
\text { 10. Service personnel can complete finish the tourists' contents of the action items } \\
\text { 11. Service personnel can clear record of tourists' information and archiving } \\
\text { 12. The effectiveness of training with professional services }\end{array}$} \\
\hline & & \\
\hline & assurance & \\
\hline & $\begin{array}{c}\text { Service } \\
\text { responsiveness }\end{array}$ & $\begin{array}{l}\text { 1. Excellent fire fighting equipment and harmonious space design at hotels } \\
\text { 2. Equipment adequate escape } \\
\text { 3. Hotel promote the concept of green building green }\end{array}$ \\
\hline & $\begin{array}{c}\text { Service } \\
\text { tangibility }\end{array}$ & $\begin{array}{l}\text { 1. Stylish building appearance merged with the environment } \\
\text { 2. Space planning and smooth movement inside and outside the hotel } \\
\text { 3. Geographic location and traffic convenience of hotel } \\
\text { 4. Excellent garden landscape design at hotels } \\
\text { 5. Exquisite and beautiful restaurant and banquet facilities in hotel } \\
\text { 6. Diverse sports facility and complete maintenance } \\
\text { 7. Practical and stylish room equipments }\end{array}$ \\
\hline & $\begin{array}{l}\text { Service } \\
\text { empathy }\end{array}$ & $\begin{array}{l}\text { 1. Excellent sound insulation effect between space and the tranquility inside the hotel } \\
\text { 2. Kind attitude and proper presence of service personnel } \\
\text { 3. Active attitude of service personnel who provide efficient service } \\
\text { 4. Rich contents and practical service web system installed by the hotel }\end{array}$ \\
\hline
\end{tabular}

Figure 1. A Hierarchical Structure of Key Assessment Indicator for Hotel in Taiwan

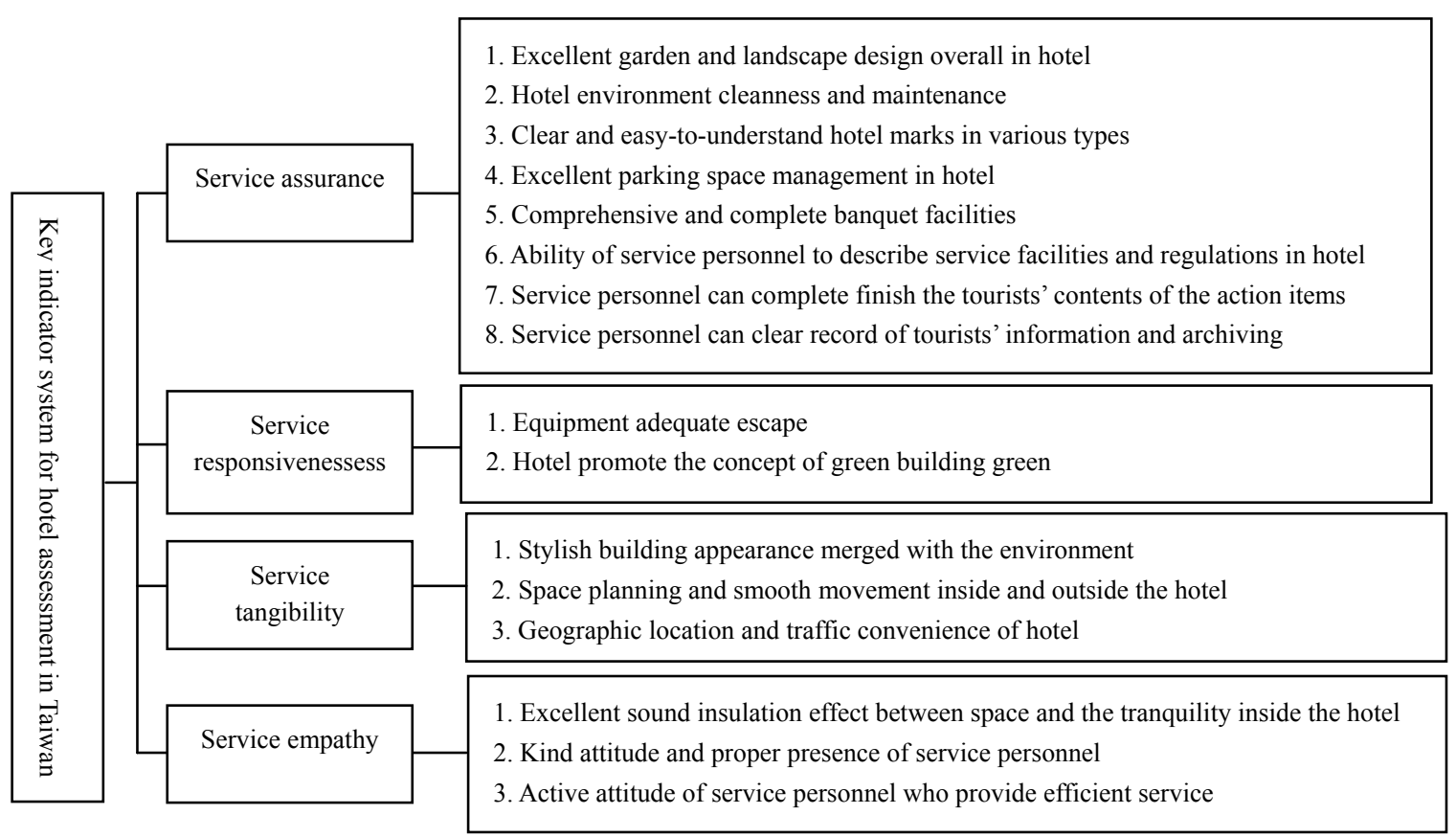

Figure 2. Second Stage Hierarchy Structure of Hotel Assessment Indicator in Taiwan 